\title{
Seasonal Variations in Urinary Excretion of Calcium
}

\author{
W. G. ROBERTSON, J. C. GALLAGHER, \\ D. H. MARSHALL, \\ M. PEACOCK, \\ B. E. C. NORDIN
}

British Medical fournal, 1974, 4, 436-437

\section{Summary}

A retrospective study over a three-year period has shown a noticeable seasonal variation in the daily urinary excretion of calcium in healthy men, healthy women, and men prone to form stones. This reached a maximum in July or August and a minimum in December or January in all three groups. For any given month the stone formers had higher urinary calcium values than healthy men, who, in turn, had higher values than healthy women.

\section{Introduction}

Recent studies in this laboratory (Aaron et al., 1974) have shown that in patients with fractures of the proximal femur the proportion with evidence of osteomalacia was highest between February and May and lowest between September and November. It was suggested that this reflected changes in vitamin $D$ activity in the body. Indeed, there is a peak in the serum level of 25-hydroxycholecalciferol, the first metabolite of vitamin $\mathrm{D}$, in the late summer (McLaughlin et al., 1974; Stamp and Round, 1974). Since the metabolites of vitamin $\mathrm{D}$ have a strong influence on the intestinal absorption of calcium (Kodicek et al., 1970; Omdahl et al., 1971) it might be expected that the absorption and possibly the urinary excretion of calcium would mirror the seasonal changes in vitamin $\mathrm{D}$ activity in the body. Indeed, observations in a few individuals have shown that urinary calcium tends to be higher in summer than in winter (McCance and Widdowson, 1943/4; Morgan et al., 1972). To test this hypothesis we analysed retrospectively urinary calcium measured in groups of healthy subjects and in a group of men with a tendency to form stones and related the excretion of calcium to the month in which the urine was passed.

\section{Subjects and Methods}

Twenty-four hour urine samples were collected with preservative from 385 men with idiopathic stones attending a renal stone clinic over three years. They were otherwise healthy and had no known metabolic disorder such as primary hyperparathyroidism, renal tubular acidosis, or urinary tract infection. All had normal renal function. The patients were on a free diet and were not on treatment at the time of study.

Twenty-four-hour urine samples were also collected from 160 healthy men and 250 healthy women, aged 20 to 60 years, who were also on a free diet.

M.R.C. Mineral Metabolism Unit, General Infirmary, Leeds LS1 3EX W. G. ROBERTSON, PH.D., M.R.c. Scientific Staff

J. C. GALLAGHER, M.R.C.P., M.R.c. Clinical Scientific Staff (present address: Department of Endocrinology, Mayo Clinic, Rochester, U.S.A.

D. H. MARSHALL, PH.D., M.R.c. Scientific Staff

M.PEACOCK, M.R.C.P., Consultant Physician, M.R.c. Clinical Scientific Staff B. E. C. NORDIN, M.D., F.R.C.P., Professor and Director of Mineral Metabolism
Urinary calcium was measured by an AutoAnalyzer pro- $\vec{F}$ cedure (N-3a) after digestion of the urine with nitric acid ? according to the method of Fales (1964). The mean daily urinary calcium excretion for each group was calculated for $\overline{\bar{m}}$ each month of the year.

\section{Results}

The mean daily urinary calcium ( \pm 1 S.E. of mean) of each group for each month of the year is shown in the fig. Allo three groups showed a definite seasonal variation in urinary calcium with a maximum occurring in July or August and a $A$ minimum in December or January. The difference between of the mean values in summer and winter was $120-150 \mathrm{mg} /$ day. $\stackrel{\vec{N}}{\mathrm{~N}}$

The significance of the difference between the minimum $A$ mean value and that of every other month of the year is $\sigma$

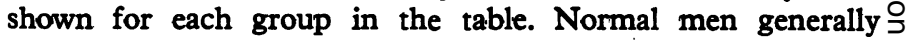
had higher urinary calcium values than normal women, and $N$ male stone formers had higher values than normal men in the $z$ same month.

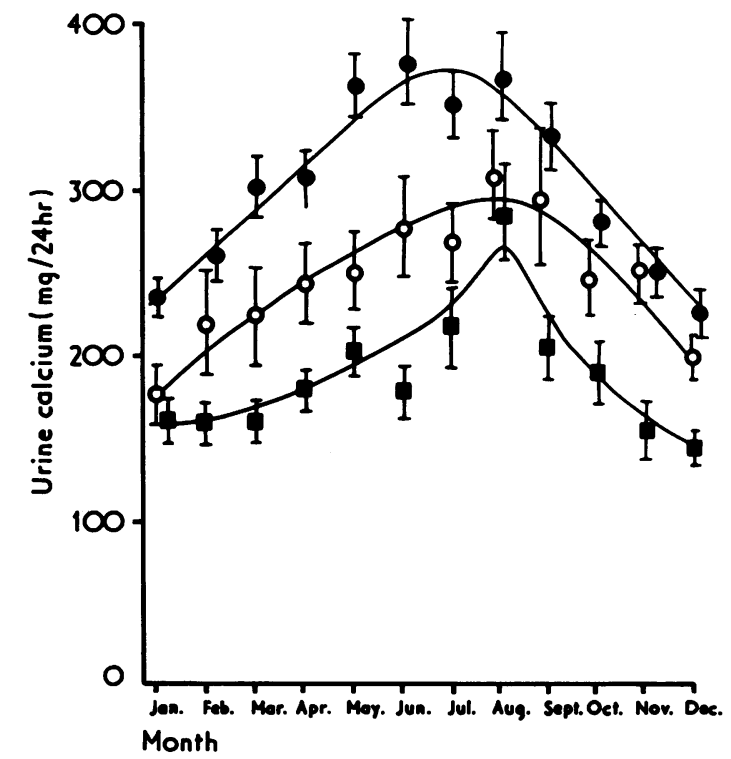

Mean daily urinary calcium ( \pm 1 S.E. of mean) in male stone formers (O), healthy men (O), and healthy women ( $D$ ) plotted according to month of year.

\section{Discussion}

The results show that there is a distinct seasonal variation in $\stackrel{+}{+}$ urinary calcium excretion and confirm the earlier observa- $T$ tions that urinary calcium is higher in summer than in win- $\frac{O}{\mathbb{D}}$ ter (MoCance and Widdowson, 1943/4; Morgan et al., 1972) $\stackrel{\frac{\rho}{1}}{\mathbb{1}}$ As expected from previous studies (Hodgkinson and Pyrah, $\unrhd$ 1958; Bulusu et al., 1970; Davis et al., 1970), the average urinary calcium of men was higher than that of women. We 8 found that this was general throughout the year (see fig.). Similarly, stone-forming men had higher urinary calcium values than normal men (Hodgkinson and Pyrah, 1958; Bulusu et al., 1970), confirming the suggestion (Robertson and Morgan, 1972) that stone formers belong to a distinct 
Significance of Difference between Minimum Mean Value of Urinary Calcium and that of Other Months in Each Group

\begin{tabular}{|c|c|c|c|c|c|c|c|c|c|c|c|c|c|}
\hline & \multicolumn{12}{|c|}{$\mathbf{P}$} \\
\hline & & Jan. & Feb. & Mar. & Apr. & May & Jun. & Jul. & Aug. & Sept. & Oct. & Nov. & Dec. \\
\hline $\begin{array}{l}\text { Male stone formers } \\
\text { Healthy men } . . \\
\text { Healthy women .. }\end{array}$ & $\begin{array}{l}\because \\
\cdots\end{array}$ & $\frac{\text { N.S. }}{\text { N.S. }}$ & $\begin{array}{l}\text { N.S. } \\
\text { N.S. }\end{array}$ & $\begin{array}{l}<0.005 \\
\text { N.S. } \\
\text { N.S. }\end{array}$ & $\begin{array}{l}<0.005 \\
<0.05 \\
<0.05\end{array}$ & $\begin{array}{l}<0.001 \\
<0.02 \\
<0.005\end{array}$ & $\begin{array}{l}<0.001 \\
<0.005 \\
<0.05\end{array}$ & $\begin{array}{l}<0.001 \\
<0.005 \\
<0.01\end{array}$ & $\begin{array}{l}<0.001 \\
<0.005 \\
<0.001\end{array}$ & $\begin{array}{l}<0.005 \\
<0.05 \\
<0.01\end{array}$ & $\begin{array}{l}<0.05 \\
<0.02 \\
<0.05\end{array}$ & $\begin{array}{l}\text { N.S. } \\
<0.01 \\
\text { N.S. }\end{array}$ & N.S. \\
\hline
\end{tabular}

N.S. $=$ Not significant.

population who excrete, on everage, about $75 \mathrm{mg} /$ day more calcium than those who do not form stones. This difference also existed throughout the year.

One possible cause of the seasonal variation in urinary calcium might be dietary changes in calcium intake. This is unlikely, however, since to increase urinary calcium by 120 $150 \mathrm{mg} /$ day would require, on average, at least a threefold increase in calcium intake in summer over that in winter (Peacock and Nordin, 1969).

Since the seasonal changes in urinary calcium seem to follow the monthly pattern of hours of sunshine it is tempting to speculate that vitamin $\mathrm{D}$ may cause the summer peak of calcium excretion through its effect on the intestinal absorption of calcium. Most reports have shown, however, that the peak in the serum level of 25-hydroxycholecalciferol occurs in late summer (McLaughlin et al., 1974; Stamp and Round, 1974), a month or two months later than the peak in urinary calcium. Thus, vitamin $\mathrm{D}$ may be only partly responsible for the summer rise in urinary calcium.

Whatever the reason for the seasonal variation in urinary calcium our observations have wide implications in the many areas of calcium metabolism where measurements of the urinary calcium level are used to assess the efficacy of a par- ticular treatment. This applies especially to treatment of calcium stone disease where many therapies include measures designed to reduce uninary calcium. Clearly, not only in studies where the patient acts as his own control but also in studies involving the use of normal healthy subjects as controls, care must be taken with the design of the experiment to ensure that comparisons are made at comparable seasons of the year.

\section{References}

Aaron, J., Gallagher, J. C., and Nordin, B. E. C. (1974). Lancet, 9, 84.

Bulusu, L., et al. (1970). Clinical Science, 38, 601.

Davis, R. H., Morgan, D. B., and Rivlin, R. S. (1970). Clinical Science, 39, 1. Fales, F. W. (1964). Clinical Chemistry, 10, 549.

Hodgkinson, A., and Pyrah, L. N. (1958). British fournal of Surgery, 46, 10. Kodicek, E., Lawson, D. E. M., and Wilson, P. W. (1970). Nature, 228, 763. McCance, R. A., and Widdowson, E. M. (1943/4). Fournal of Physiology, 102, 42 .

McLaughlin, M., et al. (1974). Lancet, 1, 536.

Morgan, D. B., Rivlin, R. S., and Davis, R. H. (1972). American fournal of Clinical Nutrition, 25, 652.

Omdahl, J., et al. (1971). Biochemistry, 10, 2935.

Peacock, M., and Nordin, B. E. C. (1969). In Proceedings of the Renal Stone Symposium, ed. A. Hodgkinson and B. E. C. Nordin, p. 253. London, Churchill.

Robertson, W. G., and Morgan, D. B. (1972). Clinica Chimica Acta, 37, 503. Stamp, T. C. B., and Round, J. M. (1974). Nature, 247, 563.

\title{
Bites by the Saw-scaled or Carpet Viper (Echis carinatus): Trial of Two Specific Antivenoms
}

\author{
D. A. WARRELL, N. McD DAVIDSON, L. D. OMEROD, HELEN M. POPE, \\ BARBARA J. WATKINS, B. M. GREENWOOD, H. A. RIED
}

British Medical fournal, 1974, 4, 437-440

\section{Summary}

Echis carinatus is the most important cause of morbidity and mortality from snake bite in Nigeria and in many other parts of the world. Forty-six patients with systemic poisoning by this snake were given echis antivenom made either by the South African Institute for Medical Research (S.A.I.M.R.) or by Behringwerke (North and West African polyvalent antivenom). A simple test of blood coagulability was used to assess whether an adequate neutralizing dose of antivenom had been given. An average of $15.2 \mathrm{ml}$ S.A.I.M.R. antivenom restored normal coagulability permanently in all 23 patients in one group, but in the other group receiving an average dose of $37.9 \mathrm{ml}$ Behringwerke antivenom normal clotting resulted in only 18 out of 23 patients. Local tissue swelling was similar in both groups, but local necrosis occurred in

Department of Medicine, Ahmadu Bello University, Zaria, Nigeria D. A. WARRELL, D.M., M.R.C.P., Consultant Physician (Present address: Hammersmith Hospital, London $\mathrm{W} 12$ 0HS)

N. McD. DAVIDSON, B.M., M.R.C.P., Senior Lecturer in Medicine L. D. OMEROD, M.B., D.T.M.\&.H., Medical Registrar HELEN M. POPE, Superintendent Technician HELEN M. POPE, Superintendent Tech

B. M. GREENWOOD, M.D., D.T.M.\&H., Senior Lecturer in Medicine

Liverpool School of Tropical Medicine, Liverpool L3 5QA

H. A. REID, M.D., F.R.C.P., Senior Lecturer in Tropical Medicine three patients treated with Behringwerke antivenom and in none given S.A.I.M.R. antivenom.

\section{Introduction}

The saw-scaled or carpet viper Echis carinatus (Schneider) fig. 1) is widely distributed throughout Africa north of the equator, the Middle East, Pakistan, India, and Sri Lanka. In this enormous area it is the most important cause of morbidity and mortality from snake bite in man. In parts of Nigeria, especially North Eastern and Benue Plateau States, $E$. carinatus bites are a serious medical problem. Several hospitals and dispensaries treat more than 150 victims each year with an overall mortality of 7-15\%. Before 1969 specific echis antivenom from the South African Institute of Medical Research (S.A.I.M.R.) was found to be very effective in rural mission hospitals. Subsequently it became difficult to import this antivenom into Nigeria and other echis antivenoms have been used, including Behringwerke North and West African polyvalent, Pasteur-Paris polyvalent and echis, and Razi Institute (Iran) echis antivenoms. The present study was prompted by reports that the mortality of echis bites treated at Guinter Memorial Hospital (Sudan Interior Mission), Bambur, North Eastern State had significantly increased as the availability of S.A.I.M.R. echis antivenom decreased (Arnett, 1971). We compared S.A.I.M.R. echis antivenom with Behringwerke North and West African polyvalent (bitis-echis-na ja) anti- 